UDC 551.510 .42

\author{
G. Milinevsky 1, 2, 3, 4, *, Yu. Yukhymchuk ${ }^{4,5}$, A. Grytsai ${ }^{3}$, V. Danylevsky ${ }^{3}$, Yu. Wang ${ }^{2}$, V. Choliy ${ }^{3}$ \\ ${ }^{1}$ National Antarctic Scientific Center, Ministry of Education and Science of Ukraine, \\ 16 Taras Shevchenko Blvd., Kyiv, 01601, Ukraine \\ ${ }^{2}$ College of Physics, International Center of Future Science, Jilin University, 2699 Qianjin Str., Changchun, 130012, China \\ ${ }^{3}$ Taras Shevchenko National University of Kyiv, 64/13, Volodymyrska St., Kyiv, 01601, Ukraine \\ ${ }^{4}$ Main Astronomical Observatory of Ukraine, National Academy of Sciences of Ukraine, \\ 27 Akad. Zabolotnogo Str., Kyiv, 03143, Ukraine \\ ${ }^{5}$ Institute of Physics, National Academy of Sciences of Ukraine, 46 Nauka Ave, Kyiv, 03028, Ukraine \\ *Corresponding author: genmilinevsky@jlu.edu.cn, genmilinevsky@gmail.com
}

\title{
PRELIMINARY COMPARISON OF THE DIRECT AEROSOL RADIATIVE FORCING OVER UKRAINE AND ANTARCTIC AERONET SITES
}

\begin{abstract}
Objectives. To analyze data on aerosol optical thickness (AOT) in the atmosphere over some Ukraine and Antarctic AERONET (AErosol RObotic NETwork) sites. To determine and compare direct aerosol radiative forcing (DRF) typical values using the data from midlatitude and Antarctic AERONET sites. Methods. Retrieval and visualization of the AERONET aerosol optical thickness and radiative forcing, data analysis and interpretation of the data. Radiative forcing evaluation using Global Atmospheric ModEl (GAME) and the AERONET operational product. Results. Aerosol optical thickness measurements are considered using observations by sun/sky photometers that are part of the AERONET sites in Ukraine (Kyiv) and at two additional sites in Antarctica (Vechernaya Hill and ARM_McMurdo sites). According to the 2015-2018 measurements at the Vechernaya Hill and ARM_McMurdo sites, the AOT values are small and are in the range of $0.05-0.1$ at the $340 \mathrm{~nm}$ wavelength. In contrast, the corresponding AOT values from Kyiv observational site are reached $0.3-0.5$ and sometimes higher. Using these AOT values from Kyiv site and the urban aerosol types, the aerosol direct radiative forcing has been evaluated by the GAME code. The top of atmosphere (TOA) DRF assessment using GAME suggests the instantaneous values of $-5.7 \mathrm{~W} \mathrm{~m}^{-2}$ over vegetation surface for AOT equal 0.1 . Conclusions. The AERONET derived aerosol optical thicknesses over Kyiv site show the mean value of 0.3 at $340 \mathrm{~nm}$; the values over two Antarctic sites are in range of 0.03 to 0.06 . Calculations using a numerical code (GAME) suggested the associated TOA instantaneous DRF of $-6 \mathrm{~W} \mathrm{~m}^{-2}$ to $-14 \mathrm{~W} \mathrm{~m}^{-2}$ over the Kyiv site. The values calculated as part of the AERONET Kyiv site operational product are about $-20 \mathrm{~W} \mathrm{~m}^{-2}$ (BOA) and about $-10 \mathrm{~W} \mathrm{~m}^{-2}$ (TOA) during 2018.
\end{abstract}

Keywords: aerosol optical thickness, aerosol radiative forcing, AERONET, GAME code.

\section{INTRODUCTION}

Aerosol particles of natural and anthropogenic origin play an essential role in climate formation and climate change (Boucher et al., 2013; Larsen et al., 2014; Menut et al., 2015; IPCC, 2019). They affect the energy balance of the atmosphere in two ways: (1) through the scattering and absorption of sunlight directly by aerosol particles (direct effect) and (2) by influencing

Cite: Milinevsky G., Yukhymchuk Yu., Grytsai A., Danylevsky V., Wang Yu., Choliy V. Preliminary comparison of the direct aerosol radiative forcing over Ukraine and Antarctic AERONET sites. Ukrainian Antarctic Journal, 2019. № 1(18), 128-138.

128 the formation processes and the physical characteristics of clouds, since aerosol particles become water vapor condensation nucleus under appropriate atmospheric conditions (indirect effect). But quantitatively, these radiation effects are estimated with very significant errors due to the significant lack of data on the spatial-temporal distribution of aerosol content in the atmosphere and on the characteristics of particles (Boucher et al., 2013; Larsen et al., 2014; Fountoulakis et al., 2019). Studies using remote groundbased and satellite lidar systems, as well as direct in situ measurements at different altitudes from aircraft (Boucher et al., 2013), indicate that the aerosol is 
concentrated the boundary layer of the troposphere (below 1-3 km). Under the influence of turbulence and various meteorological phenomena, the concentration and characteristics of the particles are very variable in space and time. The prediction of aerosol characteristics is also complicated by the short lifetime of some components, including precursor gases, which may be involved in aerosol formation ( $\mathrm{SO}_{x}, \mathrm{NO}_{x}$, and other substances). Composition of these volatile atmospheric components depends on the geographical distribution of their sources and meteorological conditions. On the basis of measurements during the 1990-2015 period and the use of different simulation methods, it was concluded that atmospheric aerosol and ozone create positive radiative forcing, the value of which globally reaches $+0.2 \mathrm{~W} \mathrm{~m}^{-2}$. In Europe, the maximum value for the same time interval is $+4.0 \mathrm{~W} \mathrm{~m}^{-2}$, in Asia it equals to $-3.0 \mathrm{~W} \mathrm{~m}^{-2}$ (Myhre et al., 2017).

The climatic effects of the aerosol depend on both the physical and chemical parameters of the aerosol particles associated with their origin. For example, 30\% of all aerosol-related effects are caused by mineral dust. It is a key component of the aerosol that acts on the climate through interaction with radiation, clouds, affects ecosystems, including human health, alters the vertical profile of temperature and cloud cover (Kudo et al., 2016). Dust and climate assessments on the global and regional scale are connected with significant uncertainties related to its high concentrations in the sparse explored regions (Ridley et al., 2016). In addition, for example, solid dust particles can be carried over a distance of more than $2500 \mathrm{~km}$ by the wind (Pey et al., 2013; Salvador et al., 2014). Powerful volcanoes can produce significant climatic effects on a global scale releasing the aerosols in the stratosphere (Hansen et al., 2005; Waquet et al., 2014).

In recent decades, the regional distribution of atmospheric aerosol has changed markedly. This is mainly due to the reduction of sulfur dioxide emissions in the US and Europe to improve air quality. At the same time, there is an increase in the amount of aerosol at south and east of Asia (Myhre et al., 2017), which, for example, creates negative aerosol radiative forcing (RF) to $-4.0 \mathrm{~W} \mathrm{~m}^{-2}$ over India.
Biomass burning has become one of the major sources of aerosol replenishment (Wu et al., 2018; Andreae, 2019). The particles resulting from the combustion are small in diameter $(30-100 \mathrm{~nm})$, but their size may vary. This is due to the fact that the aerosol undergoes rapid physical and chemical transformations (typically from minutes to hours). The change in particle size occurs through coagulation and condensation of organic material on existing particles (Laing et al., 2016). This aerosol consists predominantly of organic carbon and black carbon, which absorbs solar radiation (Kudo et al., 2016) including some inorganic material as well (Vakkari et al., 2014). The sources of this type of aerosol are concentrated predominantly in the tropical zone forests, taiga and urban areas of the Northern Hemisphere, where occasional fires of vegetation occur, as well as biomass and hydrocarbon combustion for economic purposes, in industry, vehicles. So, in September 2015, due to the forest fires and burning of peatlands, thick aerosol clouds in the form of smoke particles arrived in the atmosphere over Kyiv (Bovchaliuk et al., 2017). The optical thickness of the aerosol was so large that at altitudes higher than $500 \mathrm{~m}$ the atmosphere became opaque to the aerosol lidar CE370 (under normal atmospheric transparency conditions, this lidar can provide the measurements up to a height of $15 \mathrm{~km}$ ). The smoke screen was also clearly visible on satellite images. Extensive forest fires in central Russia during the summer of 2010 (Chubarova et al., 2012; Pere et al., 2014; Galytska et al., 2018), cause both significant increases in the aerosol content and changes of aerosol characteristics in the atmosphere over Eastern Europe. Similar events lead to an increase in the relative black carbon content among aerosols and raise their ability to absorb sunlight.

On the other hand, there are remote regions, in particular the Antarctic, where the content and characteristics of aerosols in the atmosphere are significantly different than in the above-mentioned regions, and therefore the climate effects caused by them are also different. Surface albedo in Polar Regions exceeds 0.85 that can cause positive BOA aerosol forcing due to multiple scattering (Tomasi et al., 2007). First 
AOT measurements in the Antarctica have been provided in the summer 1950/51 (Maudheim, Norway). Measurements of optical parameters were carrying out during 1960-1980s at several Antarctic stations (Mirny, South Pole, McMurdo, Molodezhnaya) with the sun photometer and pyrheliometer. Background values at $500 \mathrm{~nm}$ changed in the range $0.01-0.05$ increasing after strong volcanic eruptions, to 0.12 after El Chichon and to 0.30 after Pinatubo (Tomasi et al., 2007). Evident AOT trends in the Antarctica were not found out (Tomasi et al., 2012).

This paper compares the regional differences in the magnitude of the direct radiative forcing (DRF) basing on aerosol optical thickness at the mid-latitude site and at the Antarctic coastal sites. For comparison, measurements at three AERONET sites were used:

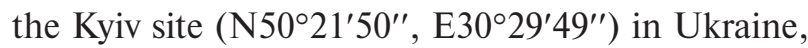
the Vechernaya Hill site (S67 39'36", E46 $09^{\prime} 28^{\prime \prime}$ ) and the ARM_McMurdo site (S77 $50^{\prime} 56^{\prime \prime}$, E166 $\left.43^{\prime} 47^{\prime \prime}\right)$ in Antarctica.

\section{DATA AND METHODS}

\section{Radiative forcing}

The effectiveness of the aerosol impact on the climate is evaluated using the concept of radiative forcing. The concept proposes a quantitative estimate of changes that the aerosol makes to the energy balance of the Earth's climate system, affecting the total flux of electromagnetic radiation at the boundary of this system. Radiative forcing is defined as the perturbation introduced by a particular component of the atmosphere into the difference between the flux of solar radiation entering the climate system and the radiation flux of the Earth's atmosphere leaving it (Committee on Radiative Forcing, 2005; Larsen et al., 2014). The total radiation flux is determined at the boundary of the Earth's climate system as the difference between the incoming flux of solar radiation $\Phi_{S}$ coming into this system and the outgoing radiation flux of the Earth's surface and atmosphere $\Phi_{E}$ leaving it (Committee on Radiative Forcing, 2005):

$$
\Phi_{S}=\frac{E_{S}}{4}\left(1-A_{E}\right)
$$

\section{0}

where $E_{S}$ - is the solar constant (the total radiative energy flux outside of the Earth atmosphere (Brasseur and Solomon 2005), $A_{E}$ is the Earth's albedo; the flux per unit surface is considered. The radiation flux from Earth is determined by the Stefan-Boltzmann law:

$$
\Phi_{E}=\sigma T_{E}^{4},
$$

where $\sigma-$ is the Stefan-Boltzmann constant, and $T_{E}$ is the effective temperature of the Earth's climate system. The total flux at the boundary of the climate system is defined as the difference between ingoing and outgoing radiation flux:

$$
\Phi=\Phi_{S}-\Phi_{E}
$$

In the case of energy equilibrium $\Phi=0$. If the equilibrium is disturbed, then the change in total flux can be estimated:

$$
\Delta \Phi=\Delta \Phi_{S}-\Delta \Phi_{E} .
$$

Obviously, changes in this flux can be caused by both changes in the ascending and the descending energy fluxes. This change, which occurs in the climate system due to external factors, is called radiative forcing. These factors can change the radiation flux from the Sun, albedo and/or the effective temperature of the climate system. Positive radiative forcing causes the system to heat up, while a negative one causes it to cool down.

The direct radiative forcing produced by aerosol particles is determined by the optical properties of these particles, their albedo and phase function. The aerosol DKF depends on the aerosol particles concentration, size, composition, morphology as well as on the solar zenith angle. In addition, the aerosol DRF depends on the ratio between the scattering and absorption capacity of the particles in the aerosol layer.

If the absorption capacity of the aerosol layer increases in comparison with the scattering, then the DRF can change from negative to positive and the aerosol layer begins to heat the atmosphere. The absorption properties depend on the size of the aerosol particles and their surface albedo. In addition, if the aerosol layer consists of a mixture of different materials, which scatter and absorb light, then this heating or cooling effect is also dependent on how these parISSN 1727-7485. Ukrainian Antarctic Journal. 2019, № 1(18) 
ticles with opposite properties are mixed. Thus, sulfates of anthropogenic origin, for which the single-scattering albedo is close to 1 , lead to negative radiative forcing (cooling), whereas black carbon aerosols (soot) have the single-scattering albedo less than 1 due to their large absorption effect.

Dust particles also provide heating of the atmosphere, absorbing both shortwave and longwave radiation. Since the effect of aerosols depends on altitude, the resulting forcing at the conventional upper boundary of the atmosphere (about $100 \mathrm{~km}$ a.s.1.) is calculated. This parameter is known as TOA (Top Of the Atmosphere), which describes the climatic role of aerosols. To estimate changes at the surface, calculations are performed at the bottom of the atmosphere, BOA (Bottom Of the Atmosphere). Total effect at different altitudes can be calculated as well. Global means of the aerosol radiative forcing in Liao et al. (2004) were retrieved as $-0.72 \mathrm{~W} / \mathrm{m}^{2}$ (TOA), and -4.04 $\mathrm{W} / \mathrm{m}^{2}$ (BOA).

\section{AERONET Data.}

Aerosol radiative forcing estimates are based on groundbased measurements, first and foremost, the AERONET (International Network of Automatic Solar Photometers (Aerosol Robotic NETwork, https://aeronet. gsfc.nasa.gov/)), which provides ground-based remote sensing observations of the optical atmospheric characteristics by standardized CIMEL318 sun-photometers (Holben et al., 1998; Giles et al., 2019). AERONET sun-photometers measure the optical thickness of the atmosphere caused by aerosols (AOT) at observations in individual narrow wavebands of the solar spectrum in the range of 340 to $1640 \mathrm{~nm}$ (in some sun-photometer modifications up to $1020 \mathrm{~nm}$ only). The wavelengths of the sun-photometers are chosen to avoid absorption the solar radiance by the atmosphere constituens (except Rayleigh scattering) such as oxygen, water vapor, ozone, etc. Measurements are made at times corresponding to the certain solar zenith angle. The sun-photometer also measures the distribution of sky brightness along the Sun's almucantarate and along height circle at specified wavelengths using two separate optical channels (Holben et al., 1998; Giles et al., 2019).
The spectral AOT measured by a sun-photometer is designated on the basis of the Beer-BouguerLambert law:

$$
E(\lambda)=E_{0}(\lambda) e^{-\tau(\lambda)},
$$

where $E(\lambda)$ - measured spectral luminosity, $E_{0}(\lambda)-$ spectral out-of-atmospheric luminosity, $\tau(\lambda)$ - spectral optical thickness of the atmosphere towards the Sun (Brasseur and Solomon, 2005). Aerosol optical thickness is defined as the integral of the extinction coefficient $\sigma(z)$ between two points with altitudes $\left(z_{1}, z_{2}\right)$ in the atmosphere (Brasseur and Solomon, 2005):

$$
\operatorname{AOT}_{\lambda}=\int_{z 1}^{z 2} \sigma(\lambda, z) d z .
$$

The optical thickness of the atmosphere is the sum of its components:

$$
\tau_{\lambda}=\tau_{\text {mol }, \lambda}+\tau_{\text {aer }, \lambda},
$$

where $\tau_{\text {mol, } \lambda}, \tau_{\text {aer, } \lambda}$ - optical thicknesses for molecules and aerosols at wavelength $\lambda$. In addition, $\tau_{\text {mol, } \lambda}$ includes the sum of the optical thicknesses of all significant molecular constituents of the atmosphere (oxygen, nitrogen, carbon dioxide) (Brasseur and Solomon, 2005). These parameters in the AERONET algorithm are determined by the conditions for the standard atmosphere according to special measurements (Holben et al., 1998; Giles et al., 2019). The total uncertainty in AOT for the AERONET measurements under cloud-free conditions is 0.01 at $440 \mathrm{~nm}$ (Holben et al., 1998).

When calculating the radiation fluxes, both direct solar and diffuse radiation from the celestial hemisphere are taken into account. These calculations are performed over a wide spectral range from 0.2 to $4.0 \mu \mathrm{m}$ (Dubovik and King, 2000). The spectrum-integrated solar radiation flux near the Earth's surface, weakened by an aerosol:

$\Phi(t, \theta, \varphi)=\int_{\lambda 1}^{\lambda 2} \Phi_{0}(t, \lambda, \theta, \varphi) \cdot \exp [-\operatorname{AOT}(t, \lambda, \theta, \varphi)] \cdot d \lambda$, where $\operatorname{AOT}(t, \lambda, \theta, \varphi)$ - is the spectral optical thickness of the aerosol measured at time $t$ in the location with coordinates $\theta, \varphi ; \Phi_{0}(t, \lambda, \theta, \varphi)$ - is the radiation flux at the upper limit of the atmosphere (about $100 \mathrm{~km}$ ). The fluxes at different altitudes are 


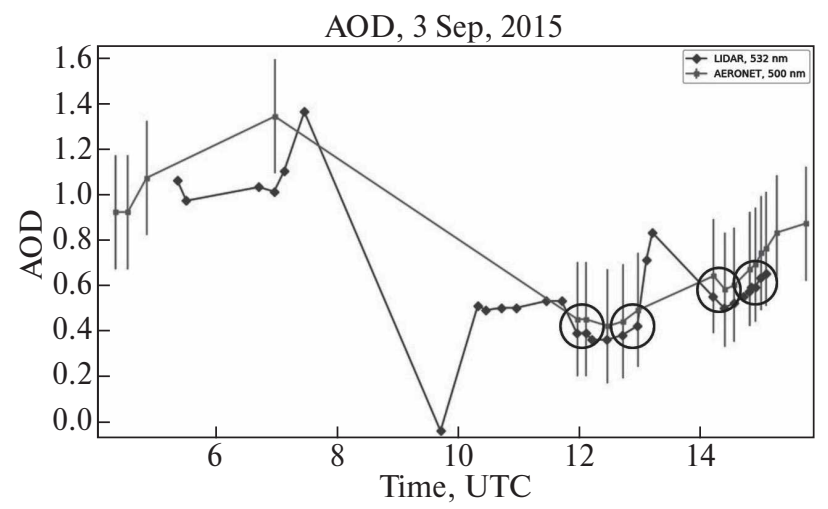

Fig. 1. AOT at $380 \mathrm{~nm}$ for observations of the AERONET network (solid curve with vertical lines showing standard deviation) and according to the lidar observations at $520 \mathrm{~nm}$ (solid curve with diamonds)
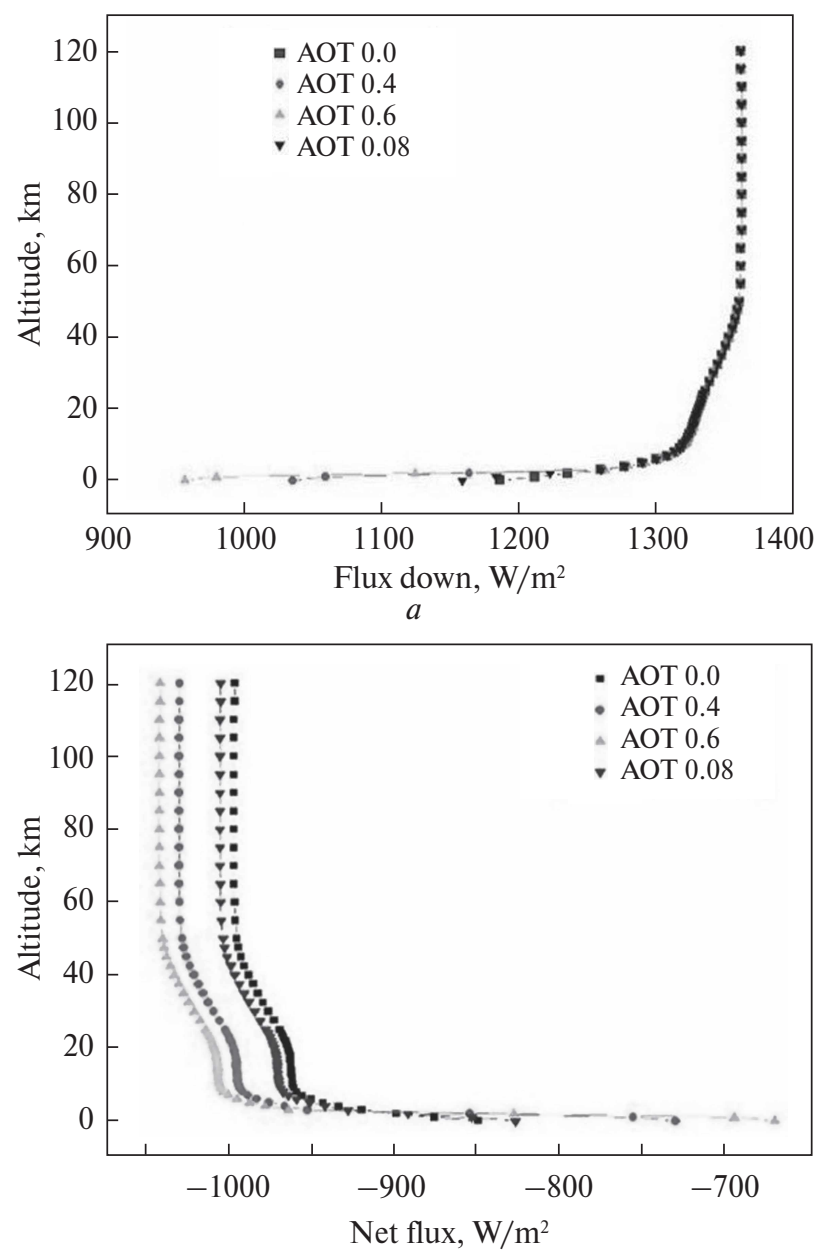

$c$ calculated using special atmospheric optical propagation models and related algorithms, including the GAME algorithm (Halthore et al., 2005; Dubuisson et al., 1996; Dubuisson et al., 2006). The GAME (Global Atmospheric ModEl) model used to calculate radiatiev fluxes and direct radiative forcing generated by aerosols and water vapor (Bassani et al., 2012; Garcia et al., 2012). In the GAME code, the radiative fluxes and heating rate of the atmosphere are calculated for atmosphere divided by 50 flat homogeneous layers in the spectral range from 0.2 to 3 microns. In calculation we assume cloudless conditions and typical albedo for vegetation surface for Kyiv site. It also accounts for Rayleigh scattering and employs standared
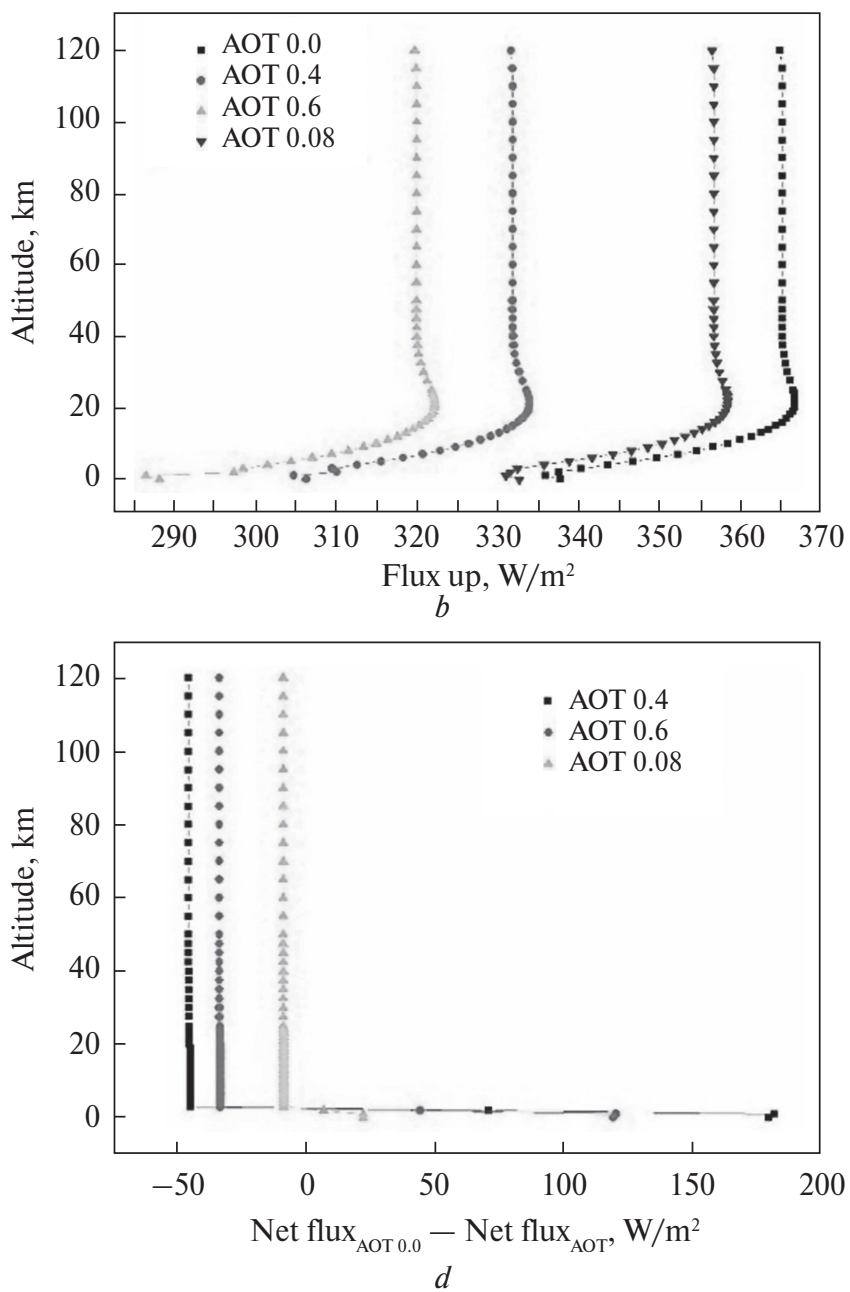

Fig. 2. The energy flux dependence on the altitude for different AOT values: $a-$ incoming flux, $b-$ outgoing flux from the surface, $c$ - their difference, $d-$ the radiative dependence on the altitude 

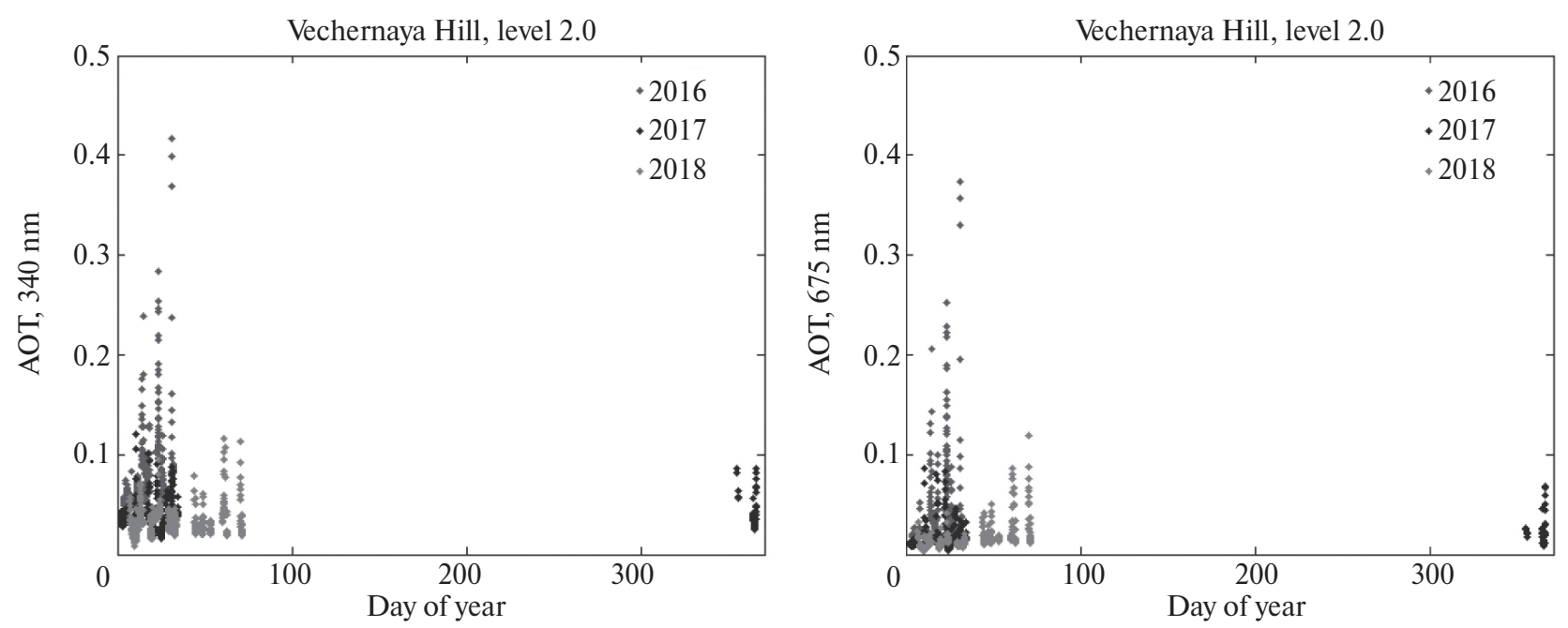

McMuro, level 2.0
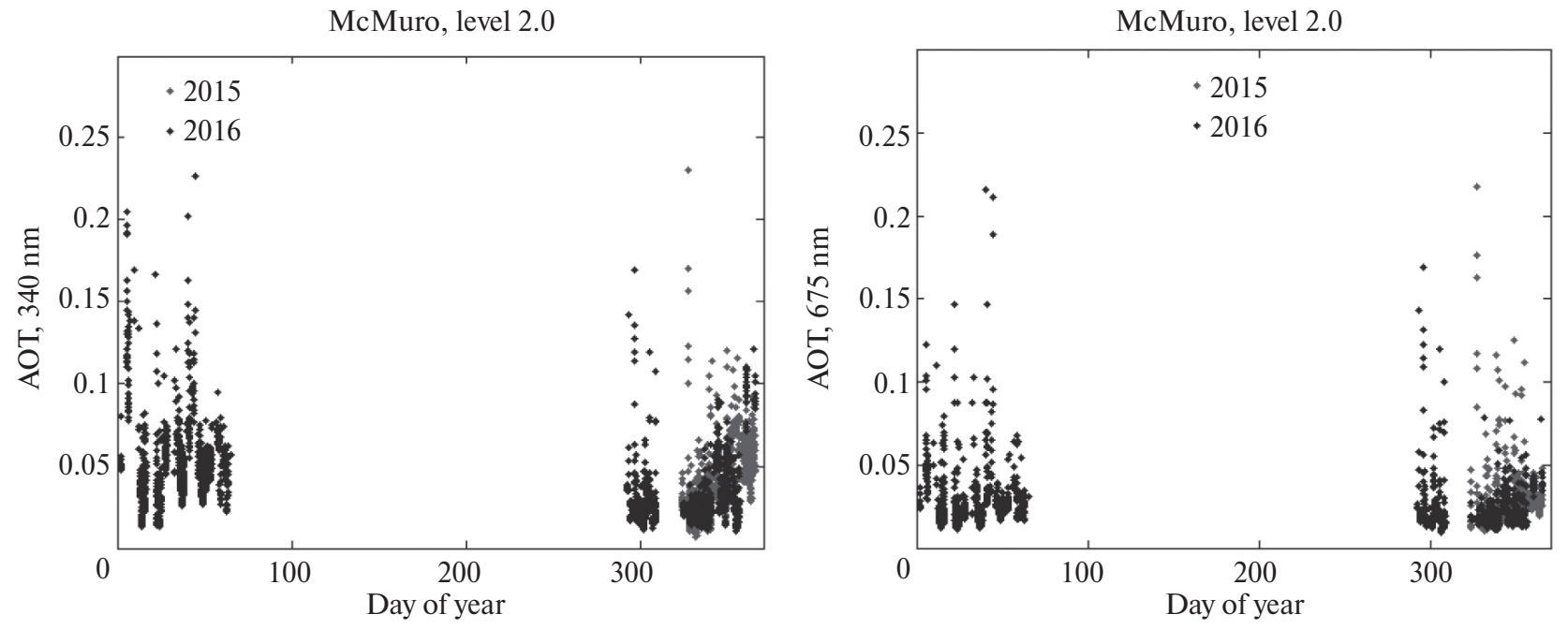

Fig. 3. Aerosol optical thickness at 340 and 675 nm for the AERONET Vechernaya Hill and ARM_McMurdo sites

atmospheric gas profiles (Dubuisson et al., 1996; 2006). Due to the preliminary DRF evaluation task for aerosol particles parameters (single scattering albedo, size distribution, etc.), the standard values were used for urban aerosol. The calculation software used in this paper was provided by the Laboratory of

Table 1. Average values of the instantaneous radiative forcing at $\mathrm{AOT}$ of $0.1,0.4,0.8$

\begin{tabular}{|l|c|c|c|}
\hline AOT & 0.1 & 0.4 & 0.8 \\
\hline Radiative forcing, $\mathrm{Wm}^{-2}$ & -5.7 & -12.4 & - \\
\hline
\end{tabular}

Atmospheric Optics, University of Lille, France. More details on the DRF computational packagescan be found in (Derimian et al., 2012; 2016; Garcia et al., 2012).

\section{RESULTS}

The DRF results obtained in this paper are the calculations of the instantaneous direct radiative forcing. For a better understanding of the effect of significant aerosol concentrations in the atmosphere on the radiative forcing, calculations were made for different values of aerosol optical thickness values: no aerosol in the atmosphere $(\mathrm{AOT}=0)$, pure atmosphere with 
Kyiv, 2018, level 2.0
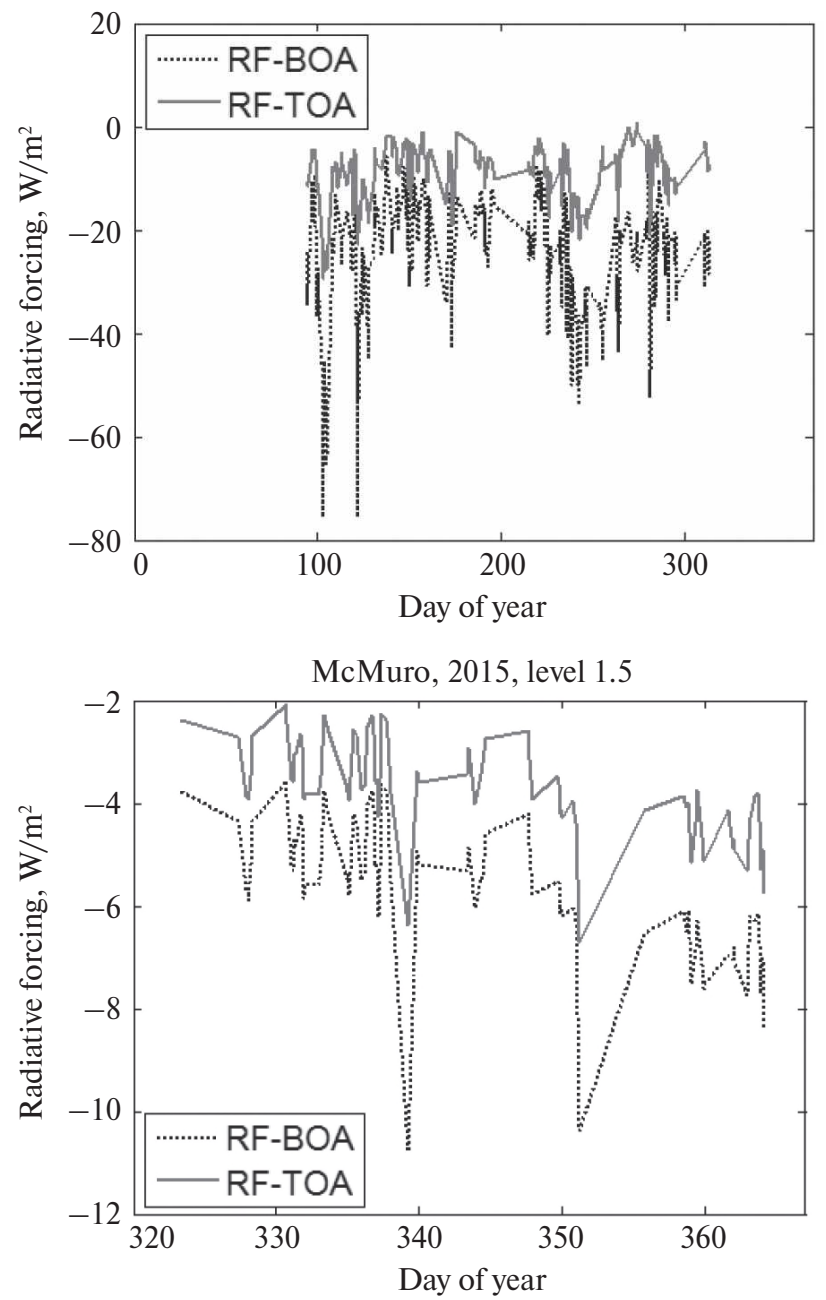

Vechernaya Hill, 2018, level 1.5

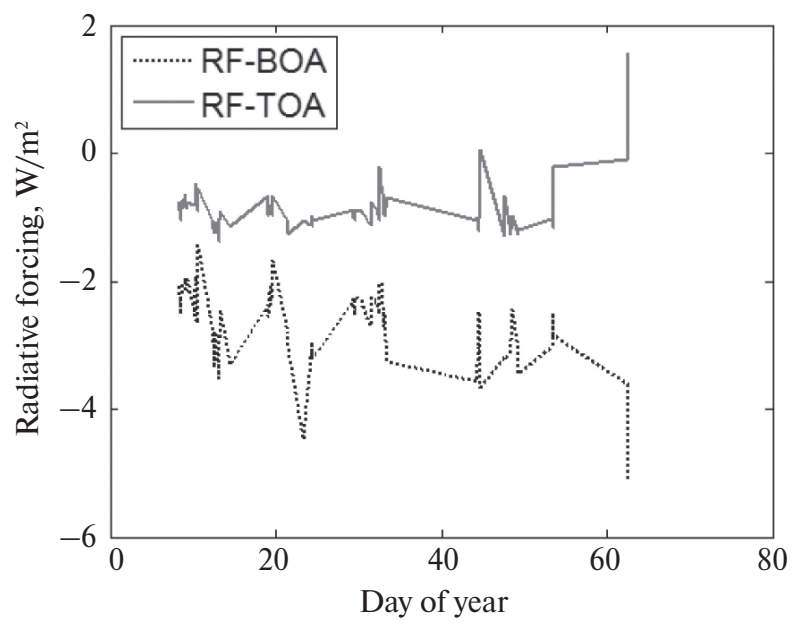

McMuro, 2016, level 1.5

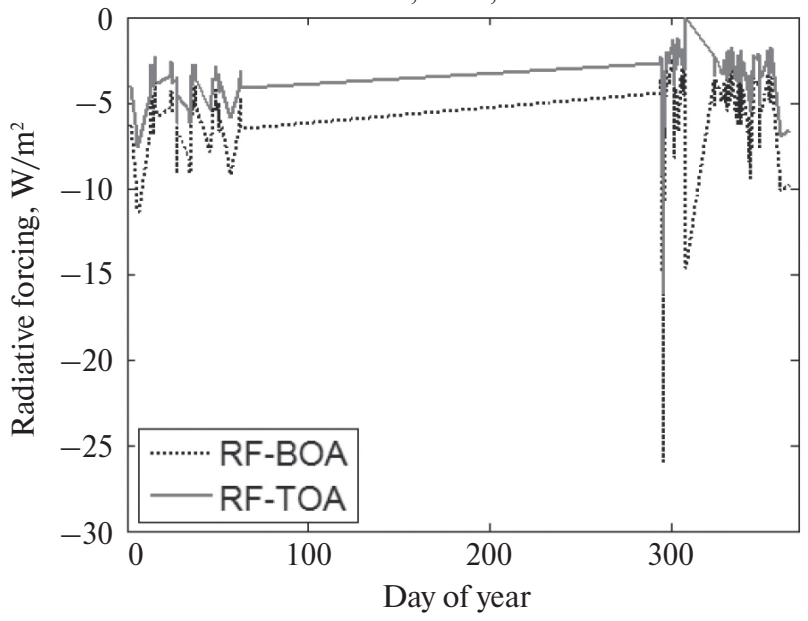

Fig. 4. The radiative forcing according to AERONET database for sites Kyiv, Vechernaya Hill (2018) and ARM_McMurdo (2015 and 2016). Radiative forcing is given on the BOA (dotted line) and the TOA (black line)

a minimum aerosol contamination $(\mathrm{AOT}=0.08,0.1)$, average pollution $(\mathrm{AOT}=0.4)$ and abnormally high values for the region of Ukraine (Milinevsky et al., 2014; Milinevsky and Danylevsky, 2018). A significant aerosol pollution was observed in the atmosphere over Kyiv, for example, during forest fires in September 2015 (Fig. 1) with AOT $=0.6 \div 1.3$ at $440-380 \mathrm{~nm}$ (Bovchaliuk et al., 2017).

The circles in Fig .1 show the results of the AOT measurements that were used to further calculate the radiative forcing. Analyzing the data of simultaneous lidar measurements, we see that in September 3,
2015, the extinction coefficient at $520 \mathrm{~nm}$ becomes high - more than $0.3 \mathrm{~km}^{-1}$, while on August 8 these values are within $0.06 \mathrm{~km}^{-1}$. The values larger than 0.3 $\mathrm{km}^{-1}$ are observed at a time when significant smoke was registered (Bovchaliuk et al., 2017). The extinction coefficient shows how a light intensity decreases due to absorption and scattering. According to Bovchaliuk et al., (2017) above $4 \mathrm{~km}$ extinction goes to zero, which means that the absorption and scattering processes have small effect on the intensity of the emitted light.

The aerosol effect on radiative forcing was estimated using the GAME numerical code. The GAME ISSN 1727-7485. Ukrainian Antarctic Journal. 2019, № 1(18) 
code computes the radiative fluxes taking into account various components. In general, as less energy reaching the surface (ingoing radiative flux), less is emitted into the space (outgoing radiative flux) as shown in Fig. 2, $a, b$. The results of simulation of the difference between the outgoing radiation flux from the Earth's surface and coming from the Sun are shown in Fig. 2

Table 1 shows the average values of instantaneous radiative forcing for different aerosol optical thickness (AOT).

Increasing the aerosol content leads to an increase in the DRF, with a corresponding sign. The characteristic values of the aerosol optical thickness in the atmosphere over Antarctica do not exceed 0.1, which is illustrated in Fig. 3. In the atmosphere above the Kyiv station at $340 \mathrm{~nm}$ wavelength AOT values are in the range $0.3-0.5$, and sometimes larger. Therefore, the direct aerosol forcing by the data at Antarctic stations are lower substantially. However, in the Antarctic atmosphere, aerosol optical thickness values of up to $0.3-0.4$ are rare recorded, which has seen by observations at the Vechernaya Hill and ARM McMurdo AERONET sites. The albedo of the Earth surface is important for radiation forcing calculations because the larger albedo produced greater the energy flux reflected from the surface. The GAME algorithm allows to calculate the aerosol radiative forcing under various types of the surface, for example, vegetation and snow conditions.

Values of the instantaneous aerosol radiative forcing at BOA and TOA are available as part of the AERONET operational product.The relevant data of the aerosol DRF for the AERONET Kyiv, Vechernaya Hill and ARM_McMurdosites are presented in Fig. 4.

The data shows that the radiative forcing is almost exclusively negative, meaning cooling of the surfaceatmosphere system. The typical RF values for the atmosphere above the AERONET Kyiv site (at the BOA the DRF is about $-22 \mathrm{~W} \mathrm{~m}^{-2}$ and at the TOA the DRF is about $-10 \mathrm{~W} \mathrm{~m}^{-2}$ ) are larger than the DRF for the atmosphere above the Antarctic sites. Note the sparce data from the Antarctic AERONET sites are due to the high Sun zenith angle and weather conditions. For comparison, the results of AERONET radiative forcing calculations for the ARM_McMurdo site for 2015 - 2016 show the typical values of radiative forcing at the BOA of $-4 \div-8 \mathrm{~W} \mathrm{~m}^{-2}$ and at the TOA $-2 \div-6 \mathrm{~W} \mathrm{~m}^{-2}$ (Fig. 4).

\section{CONCLUSIONS}

The study presents a preliminary comparison of AERONET derived AOT in the atmosphere over Kyiv site and over two Antarctic sites (Vechernaya Hill, ARM_McMurdo). The average AOT at $340 \mathrm{~nm}$ spectral wavelength in Kyiv was found to be of 0.3 , but in some episodes can even exceed 0.5 (Milinevsky et al., 2014; Milinevsky and Danylevsky, 2018). For the Antarctic atmosphere, typically low AOT values of about $0.05-0.1$ were found. The data for the Antarctic AERONET station are available for austral summer period only. The values of the radiative forcing at the TOA for the Antarctica sites are from $-2 \mathrm{~W} \mathrm{~m}^{-2}$ to -6 $\mathrm{W} \mathrm{m}^{-2}$, while the average AOT is 0.05 . To provide the comprehensive investigation of the direct radiative forcing level in the Antarctic atmosphere, the all available data from AERONET sites will be studied. The future prospects for this investigation will include the composition of aerosol over mid-latitude and Antarctic sites, as well as aerosol size distribution, single scattering albedo and clouds fraction.

Acknowledgements. This work was supported in part by State Institution National Antarctic Scientific Center, Ministry of Education and Science of Ukraine, by Main Astronomical Observatory NAS of Ukraine, and by Taras Shevchenko National University of Kyiv project 19BF051-08. The most preparation works on the paper have been done in College of Physics, International Center of Future Science, Jilin University. We thank Philippe Dubuisson from Laboratoired' Optique Atmosphérique (LOA) for providing the GAME software and valuable consultations. We thank also Brent Holben (NASA/GSFC) for managing the AERONET program and sites, principal investigators Anatoli Chaikovsky and Philippe Goloub (LOA) of the Vechernaya Hill site, principal investigator Rick Wagener and site manager Paul Ortega of the ARM_McMurdo site, and all observers 
from AERONET sites Vechernaya Hill and ARM McMurdo for their hard work in Antarctica. We thank Yevgeny Derimian (LOA) for valuable comments and suggestions that allow improving the text of the paper. The high quality of AERONET/PHOTONS data of Kyiv site was provided by CIMEL sun-photometer calibration performed at LOA, supported by ACTRIS-2 project with funding from the European Union's Horizon 2020 research and innovation program under grant agreement No 654109.

\section{REFERENCES}

1. Andreae, M. O. 2019. Emission of trace gases and aerosols from biomass burning - an updated assessment, Atmos. Chem. Phys., 19, 8523-8546, https://doi.org/10.5194/ acp-19-8523-2019.

2. Bassani, C., Cavalli, R.M., Antonelli, P. 2012. Influence of aerosol and surface reflectance variability on hyperspectral observed radiance. Atmos. Meas. Tech., 5, 11931203. doi:10.5194/amt-5-1193-2012.

3. Boucher, O., Randall, D., Artaxo, P., Bretherton, C., Feingold, G., Forster, P., Kerminen, V.-M., Kondo, Y., Liao, H., Lohmann, U., Rasch P., Satheesh, S.K., Sherwood, S., Stevens, B., Zhang, X.Y. 2013. Clouds and Aerosols. In Stocker, T.F. et al. (eds.). Climate Change 2013: The Physical Science Basis. Contribution of Working Group I to the Fifth Assessment Report of the Intergovernmental Panel on Climate Change. Cambridge University Press, Cambridge, United Kingdom and New York, NY, USA.

4. Bovchaliuk, V., Milinevsky, G., Danylevsky, V., Goloub, Ph., Sosonkin, M., Yukhimchuk, Yu., Podvin, T. 2017. Aerosol properties in atmosphere over Kyiv using lidar and sun-photometer observations. Space Sci. Technol., 23(6), 34-45. https://doi.org/10.15407/knit2017.06.034.

5. Brasseur, G.P., Solomon, S. (eds.). 2005. Aeronomy of the Middle Atmosphere: Chemistry and Physics of the Stratosphere and Mesosphere. Third Edition. Springer. 644.

6. Chubarova, N., Nezval', Ye., Sviridenkov, I., Smirnov, A., and Slutsker, I. 2012. Smoke aerosol and its radiative effects during extreme fire event over Central Russia in summer 2010. Atmos. Meas. Tech., 5, 557-568. https:// doi.org/10.5194/amt-5-557-2012, 2012.

7. Committee on Radiative Forcing Effects on Climate, Climate Research Committee, Board on Atmospheric Sciences and Climate, Division on Earth and Life Studies. 2005. Radiative Forcingof Climate Change: Expanding the Concept and Addressing Uncertainties. The National Academies Press, Washington. 224.

8. Derimian, Y., Dubovik, O., Tanre, D., Goloub, P., Lapyonok, T., \&Mortier, A. 2012. Optical properties and radiative forcing of the Eyjafjallajökull volcanic ash layer

\section{6}

observed over Lille, France, in 2010. J. Geophys. Res: Atmospheres, 117(D20). doi:10.1029/2011jd016815.

9. Derimian, Y., Dubovik, O., Huang, X., Lapyonok, T., Litvinov, P., Kostinski, A. B., Dubuisson, P., and Ducos, F. 2016. Comprehensive tool for calculation of radiative fluxes: illustration of shortwave aerosol radiative effect sensitivities to the details in aerosol and underlying surface characteristics. Atmos. Chem. Phys., 16, 57635780. https://doi.org/10.5194/acp-16-5763-2016.

10. Dubovik, O. and King, M.D. 2000. A flexible inversion algorithm for retrieval of aerosol optical properties from Sun and sky radiance measurements. Journal of Geophysical Research, 105, 20673-20696. doi: 10.1029/2000JD 900282.

11. Dubuisson, P., Buriez, J.C., Fouquart, Y. 1996. High spectral resolution solar radiative transfer in absorbing and scattering media application to the satellite simulation. Journal of Quantitative Spectroscopy and Radiative Transfer, 55(1), 103-126.

12. Dubuisson, P., Roger, J.-C., Mallet, M., Dubovik, O. 2006. A code to compute the direct solar radiative forcing: application to anthropogenic aerosols during the ESCOMPTE experiment. In: Fisher, S., Sohn, B.-J. (eds). IRS2004: Current problems in atmospheric radiation, 127130 .

13. Fountoulakis, I., Natsis, A., Siomos, N., Drosoglou, T., Bais, A.F. 2019. Deriving Aerosol Absorption Properties from Solar Ultraviolet Radiation Spectral Measurements at Thessaloniki, Greece. Remote Sens., 11, 2179. doi:10. $3390 /$ rs 11182179

14. Galytska, E., Danylevsky, V., Hommel, R., Burrows, J.P. 2018. Increased aerosols content in the atmosphere over Ukraine during summer 2010. Atmos. Meas. Tech., 11, 2101-2118. doi:10.5194/amt-11-2101-2018.

15. Garcia, O. E., Diaz, J. P., Exposito, F. J., Diaz, A. M., Dubovik, O., Derimian, Y., Dubuisson, P., Roger, J.-C. 2012. Shortwave radiative forcing and efficiency of key aerosol types using AERONET data. Atmos. Chem. Phys., 12, 5129-5145.

16. Giles, David M., Sinyuk, Alexander, Sorokin, Mikhail G., Joel S. Schafer, Alexander Smirnov, Ilya Slutsker, Thomas F. Eck, Brent N. Holben, Jasper R. Lewis, James R. Campbell, Ellsworth J. Welton, Sergey V. Korkin, and Alexei I. Lyapustin. 2019. Advancements in the Aerosol Robotic Network (AERONET) Version 3 database - automated near-real-time quality control algorithm with improved cloud screening for Sun photometer aerosol optical depth (AOD) measurements. Atmospheric Measurement Techniques, 12 (1), 169-209. doi:10.5194/amt-12-169-2019.

17. Halthore, R.N., Crisp, D., Schwartz, S.E., Anderson, G.P., Berk, A., Bonnel, B., Boucher, O., Chang, F.-L., Chou, M.-D., Clothiaux, E.E., Dubuisson, P., Fomin, B., Fouquart, Y., Freidenreich, S., Gautier, C., Kato, S., Laszlo, 
I., Li, Z., Mather J.H., Plana-Fattori, A., Ramaswamy, V., Ricchiazzi, P., Shiren, Y., Trishchenko, A., Wiscombe, W. 2005. Intercomparison of shortwave radiative transfer codes and measurements. J. Geophys. Res., 110, D11206.

18. Hansen, J., Sato, M., Ruedy, R., Nazarenko, L., Lacis, A., Schmidt, G. A., Russell, G., Aleinov, I., Bauer, M., Bauer, S., Bell, N., Cairns, B., Canuto, V., Chandler, M., Cheng, Y., Del Genio, A., Faluvegi, G., Fleming, E., Friend, A., Hall, T., Jackman, C., Kelley, M., Kiang, N., Koch, D., Lean, J., Lerner, J., Lo, K., Menon, S., Miller, R., Minnis, P., Novakov, T., Oinas, V., Perlwitz, Ja., Perlwitz, Ju., Rind, D., Romanou, A., Shindell, D., Stone, P., Sun, S., Tausnev, N., Thresher, D., Wielicki, B., Wong, T., Yao, M., and Zhang, S. 2005. Efficacy of climate forcings. $J$. Geophys. Res., 110, D18104, doi:10.1029/2005JD005776.

19. Holben, B.N., Eck, T.F., Slutsker, I., Tanré, D., Buis, J.P., Setzer, A., Vermote, E., Reagan, J.A., Kaufman, Y.J., Nakajima, T., Lavenu, F., Jankowiak, I., Smirnov, A. 1998. AERONET - A federated instrument network and data archive for aerosol characterization. Rem. Sens. Env., $66(1), 1-16$.

20. IPCC, 2019: IPCC Special Report on the Ocean and Cryosphere in a Changing Climate. [H.-O. Pörtner, D.C. Roberts, V. Masson-Delmotte, P. Zhai, M. Tignor, E. Poloczanska, K. Mintenbeck, M. Nicolai, A. Okem, J. Petzold, B. Rama, N. Weyer (eds.)]. https://www.ipcc.ch/ site/assets/uploads/sites/3/2019/11/SROCC_Final Draft_FullReport.pdf (accessed: 12.09.2019).

21. Kudo, R., Nishizawa, T., Aoyagi, T. 2016. Vertical profiles of aerosol optical properties and the solar heating rate estimated by combining skyradiometer and lidar measurements. Atmos. Meas. Tech., 9, 3223-3243.

22. Laing, J.R., Jaffe, D.A., Hee, J.R. 2016. Physical and optical properties of aged biomass burning aerosol from wildfires in Siberia and the Western USA at the Mt. Bachelor Observatory. Atmos. Chem. Phys., 16, 15185-15197.

23. Larsen, J.N., Anisimov, O.A., Constable, A., Hollowed, A.B., Maynard, N., Prestrud, P., Prowse, T.D., and Stone, J.M.R. 2014. Polar regions. In: Climate Change 2014: Impacts, Adaptation, and Vulnerability. Part B: Regional Aspects. Contribution of Working Group II to the Fifth Assessment Report of the Intergovernmental Panel on Climate Change [Barros, V.R., C.B. Field, D.J. Dokken, M.D. Mastrandrea, K.J. Mach, T.E. Bilir, M. Chatterjee, K.L. Ebi, Y.O. Estrada, R.C. Genova, B. Girma, E.S. Kissel, A.N. Levy, S. MacCracken, P.R. Mastrandrea, and L.L. White (eds.)]. Cambridge University Press, Cambridge, United Kingdom and New York, NY, USA, 1567-1612.

24. Liao, H., Seinfeld, J. H., Adams, P. J., Mickley, L. J. 2004. Global radiative forcing of coupled tropospheric ozone and aerosols in a unified general circulation model. $J$. Geophys. Res., 109, D16207, doi:10.1029/2003JD00445 6.
25. Menut, L., Siour, G., Mailler, S., Couvidat, F., Bessagnet, B. 2016. Observations and regional modeling of aerosol speciation and size distribution over Africa and Europe. Atmos. Chem. Phys., 16, 12961-12982.https://doi.org/10. 5194/acp-16-12961-2016

26. Milinevsky, G., Danylevsky, V., Bovchaliuk, V., Bovchaliuk, A., Goloub, Ph., Dubovik, O., Kabashnikov, V., Chaikovsky, A., Miatselskaya, N., Mishchenko, M., and Sosonkin, M. 2014. Aerosol seasonal variations over urban-industrial regions in Ukraine according to AERONET and POLDER measurements. Atmos. Meas. Tech., 7, 1459-1474.

27. Milinevsky, G., Danylevsky, V. 2018. Atmospheric Aerosol Over Ukraine Region: Current Status of Knowledge and Research Efforts. Front. Environ. Sci., 6, 59.

28. Myhre, G., Aas, W., Cherian, R., Collins, W., Faluvegi, G., Flanner, M., Forster, P., Hodnebrog, Ø., Klimont, Z., Lund, M. T., Mülmenstädt, J., Lund Myhre, C., Olivié, D., Prather, M., Quaas, J., Samset, B. H., Schnell, J. L., Schulz, M., Shindell, D., Skeie, R. B., Takemura, T., and Tsyro, S. 2017. Multi-model simulations of aerosol and ozone radiative forcing due to anthropogenic emission changes during the period 1990-2015. Atmos. Chem. Phys., 17, 2709-2720. https://doi.org/10.5194/acp-172709-2017.

29. Pere, J. C., Bessagnet, B., Mallet, M., Waquet, F., Chiapello, I., Minvielle, F., Pont, V., Menut, L. 2014. Direct radiative effect of the Russian wildfires and its impact on air temperature and atmospheric dynamics during August 2010. Atmos. Chem. Phys., 14. 1999 -2013.

30. Pey, J., Querol, X., Alastuey, A., Forastiere, F., and Stafoggia, M. 2013. African dust outbreaks over the Mediterranean Basin during 2001-2011: PM10 concentrations, phenomenology and trends, and its relation with synoptic and mesoscale meteorology. Atmos. Chem. Phys., 13, 1395-1410, https://doi.org/10.5194/acp-13-1395-2013.

31. Ridley, D.A., Heald, C.L., Kok, J.F., Zhao, Ch. 2016. An observationally-constrained estimate of global dust aerosol optical depth. Atmos. Chem. Phys., 16, 15097-15117.

32. Salvador, P., Alonso-Pérez, S., Pey, J., Artínano, B., de Bustos, J. J., Alastuey, A., and Querol, X. 2014. African dust outbreaks over the western Mediterranean Basin: 11-year characterization of atmospheric circulation patterns and dust source areas. Atmos. Chem. Phys., 14, 6759-6775, https://doi.org/10.5194/acp-14-6759-2014, 2014.

33. Tomasi, C., Vitale, V., Lupi, A., Di Carmine, C., Campane1li, M., Herber, A., Treffeisen, R., Stone, R. S., Andrews, E., Sharma, S., Radionov, V., von Hoyningen-Huene, W., Stebel, K., Hansen, G. H., Myhre, C. L., Wehrli, C., Aaltonen, V., Lihavainen, H., Virkkula, A., Hillamo, R., Strom, J., Toledano, C., Cachorro, V. E., Ortiz, P., de Frutos, A. M., Blindheim, S., Frioud, M., Gausa, M., Zielinski, T., Petelski, T., and Yamanouchi, T. 2007. 
Aerosols in polar regions: A historical overview based on optical depth and in situ observations. J. Geophys. Res., 112, D16205, doi:10.1029/ 2007JD008432.

34. Tomasi, C., Lupi, A., Mazzola, M., Stone, R. S., Dutton, E. G., Herber, A., Radionov, V. F., Holben, B. N., Sorokin, M. G., Sakerin, S. M., Terpugova, S. A., Sobolewski, P. S., Lanconelli,C., Petkov, B. H., Busetto, M., and Vitale, V. 2012. An update on polar aerosol optical properties using POLAR-AOD and other measurements performed during the International Polar Year. Atmospheric Environment, 52, 29-47.

35. Vakkari, V., Kerminen, V.-M., Beukes, J.P., Tiitta, P., van Zyl, P.G., Josipovic, M., Venter, A.D., Jaars, K., Worsnop, D.R., Kulmala, M., Laakso, L. 2014. Rapid changes in biomass burning aerosols by atmospheric oxidation. Geophys. Res. Lett., 41(7), 2644-2651.

36. Waquet, F., Peers, F., Goloub, P., Ducos, F., Thieuleux, F., Derimian, Y., Riedi, J., Chami, M., and Tanré, D. 2014. Retrieval of the Eyjafjallajökull volcanic aerosol optical and microphysical properties from POLDER/PARASOL measurements. Atmos. Chem. Phys., 14, 1755-1768, https:// doi.org/10.5194/acp-14-1755-2014.

37. Wu, J., Kong, S., Wu, F., Cheng, Y., Zheng, S., Yan, Q., Zheng, H., Yang, G., Zheng, M., Liu, D., Zhao, D., and Qi, S. 2018. Estimating the open biomass burning emissions in central and eastern China from 2003 to 2015 based on satellite observation. Atmos. Chem. Phys., 18, 1162311646, https://doi.org/10.5194/acp-18-11623-2018.

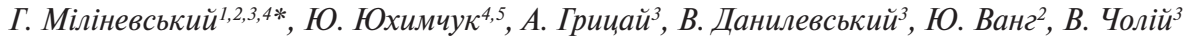

${ }^{1}$ Національний антарктичний науковий центр МОН України, бульв. Тараса Шевченка, 16, м. Київ, 01601, Україна

${ }^{2}$ Коледж фізики, Міжнародний центр науки майбутнього, Цзилінський університет, вул. Цянцин, 2699, м. Чанчунь, 130012, Китай,

${ }^{3}$ Київський національний університет імені Тараса Шевченка, вул. Володимирська, 64/13, м. Київ, 01601, Україна

${ }^{4}$ Головна астрономічна обсерваторія НАН України, вул. Академіка Заболотного, 27, м. Київ, 03143, Україна

${ }^{5}$ Інститут фізики НАН України, пр. Науки, 46, м. Київ, 02000, Україна

* Автор для кореспонденції: genmilinevsky@jlu.edu.cn, genmilinevsky@gmail.com

\section{ПОПЕРЕДНІ ПОРІВНЯННЯ ПРЯМОГО АЕРОЗОЛЬНОГО РАДІАЦЙНОГО ФОРСИНГУ ЗА ДАНИМИ СТАНЦІЙ АЕRОNЕТ В УКРАЇНI ТА АНТАРКТИЦІ}

РЕФЕРАТ. Мета. Проаналізувати дані щодо аерозольної оптичної товщини (АОТ) в атмосфері на деяких пунктах мережі AERONET (AErosol RObotic NETwork) в Україні та Антарктиці. Для визначення та порівняння типових значень аерозольного прямого радіаційного форсингу (ПРФ) використати типові дані середньоширотної та двох антарктичних пунктів AERONET. Методи. Визначення та візуалізація даних AERONET щодо оптичної товщини аерозолю та радіаційний форсинг, проведення аналізу та інтерпретації цих даних. Обчислення радіаційного форсингу за допомогою алгоритму Глобальна атмосферна модель (Global Atmospheric ModEl, GAME). Результати. Розглянуто вимірювання аерозольної оптичної товщини за спостереженнями за допомогою аерозольних сонячних фотометрів мережі AERONET в Україні (пункт Київ) та у двох пунктах спостережень в Антарктиді (Гора Вечірня та АРМ_МакМердо (ARM_McMurdo)). Відповідно до вимірювань 2015-2018 pр. визначено, що за даними пунктів Гора Вечірня та APM_ МакМердо значення АОТ є невеликими і знаходяться в діапазоні 0.05-0.1 на довжині хвилі 340 нм. На відміну від вимірювань в Антарктиці, на пункті AERONET Київ відповідні значення АOT сягають понад 0.3-0.5. Використовуючи значення АОТ з пункту Київ було оцінено прямий аерозольний радіаційний форсинг за допомогою алгоритму GAME. Розрахунки за GAME визначають аерозольний ПРФ на рівні -5.7 Вт м ${ }^{-2}$ над поверхнею з рослинністю, коли оптична товщина аерозолю дорівнює 0.1. Висновки. Оптична товщина аерозолю за даними AERONET в атмосфері над пунктом Київ має середнє значення АОТ, що дорівнює 0.3 (340 нм), значення АОТ над двома антарктичними пунктами знаходяться в межах від 0.03 до 0.06. Оцінки з використанням чисельного коду (GAME) дають величини ПРФ від -6 Вт м $^{-2}$ до -14 Вт м ${ }^{-2}$ над пунктом Київ. Значення, обчислені в рамках оперативного продукту AERONET за даними пункту Київ, становлять близько -20 Вт м $^{-2}$ (нижня границя атмосфери) та близько -10 Вт м $^{-2}$ (верхня границя атмосфери) протягом 2018 року.

Ключові слова: аерозольна оптична товщина, радіаційний форсинг, AERONET, алгоритм Глобальна атмосферна модель (GAME) 